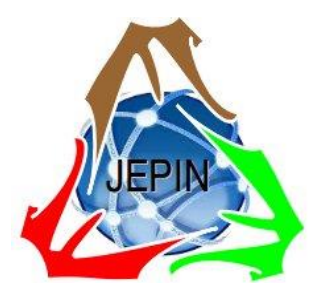

JEPIN

(Jurnal Edukasi dan Penelitian Informatika)

Vol. 7

No. 2

ISSN(e): 2548-9364 / ISSN(p) : 2460-0741

\title{
Perbandingan Klasifikasi dengan Pendekatan Pembelajaran Mesin untuk Mengidentifikasi Tweet Hoaks di Media Sosial Twitter
}

\author{
Shanto Moyrano Tambunan ${ }^{\# 1}$, Yessica Nataliani ${ }^{\# 2}$, Elizabeth Sri Lestari ${ }^{\# 3}$

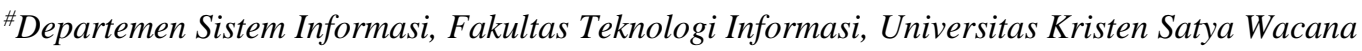 \\ Jl. Diponegoro No. 52-60, Salatiga 50711 \\ 1682017148 estudent.uksw. edu \\ ${ }^{2}$ yessica.natalianieuksw.edu \\ ${ }^{3}$ elizabeth@uksw. edu
}

\begin{abstract}
Abstrak - Perkembangan teknologi tidak luput dari dampak negatif, salah satunya hoaks. Twitter menjadi salah satu media sosial yang paling aktif digunakan sebagai pertukaran informasi, komunikasi, dan hiburan. Oleh karena itu pengguna Twitter dapat menyebarkan berita atau hoaks dengan mudah. Penelitian ini bertujuan mengidentifikasi tweet yang berisi informasi hoaks maupun valid menggunakan pembelajaran mesin. Algoritma yang digunakan adalah Stochastic Gradient Descent, Nä̈ve Bayes, Random Forest, dan Rocchio. Keempat algoritma tersebut dibandingkan untuk kemudian dicari hasil terbaik dalam mengidentifikasi dan memverifikasi tweet di Twitter yang berisi hoaks atau informasi valid secara otomatis. Kata kunci yang digunakan adalah Corona, Mutasi Corona, PSBB, Dana Bansos, Dana Otsus, Utang Pemerintah, dan Sekolah Tatap Muka sebanyak 898 tweet. Data dikelompokkan berdasarkan kelas hoaks dan valid lalu diolah menjadi dataset dengan melewati tahap pra-proses hingga pembobotan kata dengan TF-IDF. Hasil pengujian menunjukkan algoritma Stochastic Gradient Descent merupakan algoritma terbaik dengan hasil akurasi rata-rata sebesar $84.92 \%$. Pengujian lanjutan dilakukan dengan menghitung nilai presisi, recall, dan F-1. Hasil presisi terbaik sebesar $82.95 \%$ pada algoritma Naïve Bayes, sedangkan hasil recall dan F-1 terbaik didapat dari algoritma Stochastic Gradient Descent sebesar $85.05 \%$ dan $82.42 \%$.
\end{abstract}

Kata kunci- Klasifikasi, Hoaks, Tweet, Pembelajaran Mesin, Random Forest, Nä̈ve Bayes, Stochastic Gradient Descent, Rocchio

\section{Pendahuluan}

Kemajuan teknologi tidak bisa dihindari dalam kehidupan manusia. Teknologi akan terus berkembang dan berinovasi untuk memberikan banyak manfaat bagi masyarakat. Namun efek dari kemajuan teknologi tidak akan terlepas dari dampak negatif. Seiring bertambah banyaknya informasi berita online yang tersebar secara luas, kualitas berita yang tersebar pun berkurang.
Informasi merupakan hasil pengolahan data menjadi sesuatu yang berguna bagi penerimanya. Informasi berfungsi untuk menambah wawasan karena dapat menggambarkan suatu permasalahan sehingga penerima dapat mengambil keputusan lebih cepat. Informasi juga dapat digunakan sebagai sarana membantu orang lain. Dalam penyampaian informasi, inti dari informasi sangatlah penting antara lain waktu, ruang atau tempat, serta hubungan keterkaitan antar situasi sehingga tidak menimbulkan kesalahtafsiran. Sumber informasi berasal dari data yang sesuai dengan kenyataan atau berdasar kejadian. Seperti halnya berita yang disebarkan lewat media sosial [1].

Teknologi informasi merupakan sebuah pengolahan dan pendistribusian informasi dalam bentuk digital ataupun elektronik. Teknologi informasi secara sederhana sebagai ilmu berbasis komputer di bidang informasi dan perkembangannya sangat pesat. Adanya perkembangan teknologi tersebut, membuat segala aktivitas di dunia nyata dapat dilakukan melalui dunia maya. Akses untuk internet menjadi lebih mudah dan efisien, mulai dari menjual produk, pesan singkat, hingga mencari informasi.

Menurut survei yang dilakukan oleh Assosiasi Penyelenggara Jasa Internet Indonesia [2] dalam periode 2019/2020-kuartal II, terdapat 196,7 juta pengguna internet, dalam arti sama dengan $73.7 \%$ penduduk Indonesia. Bahkan dari lima negara, Indonesia menjadi salah satu negara yang memiliki pengguna internet terbanyak. Banyaknya aktivitas terkait berita di media sosial dapat menjadi masalah akan validnya informasi.

Kabar bohong atau hoaks masih menjadi permasalahan besar di Indonesia, yang dapat menimbulkan kerugian baik bagi seseorang, kelompok, organisasi, ataupun pemerintah. Twitter menjadi salah satu sosial media yang paling sering digunakan, dimana tiap kicauannya (posting-an) berformat 140 kata. Hal tersebut membuat informasi menjadi mudah disebarkan dan informasi terbaru yang viral dapat dilihat melalui menu trending-nya. 
Hoaks merupakan tindakan memanipulasi data atau informasi yang dapat mempengaruhi opini pembaca, sehingga data atau informasi yang terindikasi hoaks tidak sesuai dengan fakta yang ada. Meskipun pemerintah Indonesia sudah melakukan banyak tindakan pencegahan hoaks, tapi masih banyak berita bohong yang tersebar di media social, yang dapat berdampak buruk dan merugikan banyak pihak. Survei yang dirilis oleh Masyarakat Telematika Indonesia (Mastel) tentang informasi palsu bahwa media sosial menjadi saluran penyebaran paling tinggi dengan persentase $87.5 \%$ [3].

Informasi hoaks di media sosial kebanyakan topik yang sedang viral. Beberapa topik yang sedang viral di Twitter beberapa bulan terakhir yang diangkat pada penelitian ini antara lain kesehatan, pendidikan, dan ekonomi. Oleh karena itu untuk menghindari dampak buruk tersebut, penelitian ini akan membantu mengetahui seberapa besar pembelajaran mesin (machine learning) mengidentifikasi kemungkinan hoaks di media sosial Twitter.

Penelitian yang dikembangkan adalah untuk melakukan perbandingan klasifikasi dengan pendekatan pembelajaran mesin untuk mengidentifikasi tweet hoaks di media sosial Twitter. Data dikumpulkan dengan metode Web Crawling menggunakan bahasa pemrograman Python dari tanggal 1 Maret 2021 hingga 15 April 2021. Algoritma yang digunakan adalah Stochastic Gradient Descent (SGD), Nä̈ve Bayes, Random Forest dan Rocchio. Keempat algoritma tersebut diambil karena memiliki kemampuan supervised learning, yakni data dikumpulkan lalu dilakukan pre-processing, dan nantinya akan dilatih dengan pembelajaran mesin untuk dapat memprediksi dan mengklasifikasi suatu berita merupakan hoaks atau bukan.

Stochastic Gradient Descent dipilih menjadi metode yang dibandingkan karena metode ini merupakan salah satu metode klasifikasi yang memiliki performa yang baik untuk data yang berdimensi besar. SGD juga mempunyai akurasi yang tinggi, sehingga menjadikannya lebih presisi [4]. Sementara itu, algoritma Nä̈ve Bayes juga dibandingkan karena metode tersebut merupakan metode klasifikasi yang cukup sederhana, yang menerapkan teorema Bayes, sehingga semua fitur dianggap tidak saling berhubungan. Dengan kata lain, jika ada fitur tertentu dari kelas, fitur tersebut tidak memiliki hubungan dengan fitur yang lain [5].

Random Forest menjadi pilihan lain perbandingan karena akurasinya dapat ditingkatkan dengan metode pemilihan data secara acak, yang dapat memanggil anak simpul dari setiap node (simpul atasnya). Hasil akumulasi dari setiap simpul pohon dipilih yang paling banyak muncul [6]. Semakin banyak pohon akan mempengaruhi tingkat akurasi, sehingga metode ini sangat baik dalam menangani data yang banyak dan dapat menyeimbangkan kesalahan (error). Algoritma Rocchio dipilih karena memiliki kinerja yang lebih baik dari Nä̈ve Bayes pada penelitian sebelumnya, yaitu dengan melakukan perhitungan batas kelas menggunakan centroid dalam menetapkan hasil batas-batasnya [7].

\section{LANDASAN TEORI}

Klasifikasi berita atau informasi mengenai hoaks telah dilakukan pada beberapa penelitian. Salah satunya tentang pengembangan penyaringan hoaks berbahasa Indonesia, yang berdasar pada gambaran vektor dalam Term Frequency serta Document Frequency dengan teknik klasifikasinya. Penelitian tersebut menggunakan algoritma Support Vector Machine (SVM) serta SGD. Pada klasifikasi SGD yang menggunakan Huber, yang telah dimodifikasi, diperoleh akurasi tertinggi dengan persentase modifikasi $86 \%$, berasal dari 100 data hoaks dan 100 situs web bukan hoaks, dengan pemilihan acak sebagai proses pelatihan di luar dataset [4]

Pada penelitian analisis sentimen data Twitter Bahasa Indonesia yang ditulis oleh Pantouw (2017) untuk mengetahui informasi dari data tweet, diklasifikasikan menjadi sentimen positif, negatif, serta netral. Penelitian tersebut dilakukan dengan metode klasifikasi Multinomial Nä̈ve Bayes dan Rocchio dengan akurasi tertinggi dipereoleh Rocchio sebesar 96.28\%. Nilai tersebut didapat setelah melakukan pelabelan ulang dan pemotongan yang akhirnya mengalami peningkatan [5].

Selain itu penelitian tentang eksperimen pada sistem klasifikasi berita hoaks berbahasa Indonesia berbasis pembelajaran mesin membahas tentang klasifikasi berita hoaks berbahasa Indonesia menggunakan pembelajaran mesin. Dengan menggunakan algoritma Nä̈ve Bayes, Support Vector Machine (SVM) dan C4.5. Dari penelitian tersebut disimpulkan bahwa dalam klasifikasi teks, algoritma C4.5 dan SVM memiliki keakuratan yang cukup tinggi tanpa seleksi fitur. Namun pada hasil seleksi fitur, algoritma Nä̈ve Bayes menjadi salah satu yang paling unggul [8].

Dalam penelitian lain dikembangkan analisis dan deteksi konten berita hoaks di Indonesia berdasarkan pembelajaran mesin. Penelitian ini menggunakan lima teknik klasifikasi. Akurasi tertinggi diperoleh dari pengklasifikasi Random Forest sebesar $76.46 \%$ setelah menggunakan presisi, recall, F-1, dan akurasi. Data yang diambil sebanyak 251 artikel berita online yang terdiri dari 151 artikel bukan hoaks dan 100 artikel hoaks [9].

Penelitian lain tentang identifikasi berita hoaks di media sosial Twitter dijelaskan tentang bagaimana cara mengidentifikasi berita hoaks melalui tweet. Identifikasi dilakukan menggunakan klasifikasi Decision Tree C4.5 dengan perbandingan seleksi fitur dari pembobotan, Term Frequency-Inverse Document Frequency (TF-IDF), serta $n$-gram. Dari penelitian tersebut didapatkan hasil bahwa seleksi fitur TF-IDF memiliki dampak yang signifikan, sehingga memungkinkan sistem untuk tidak menggunakan bobot data yang terlalu banyak pada penggunaan fitur yang banyak muncul data, sehingga menjadikannya lebih akurat dalam menentukan topik yang dibahas [10].

\section{A. Berita}

Informasi yang dapat menarik pembaca yang dapat disampaikan melalui beberapa media disebut dengan berita. Media yang dapat digunakan untuk menyebarkan 
berita antara lain koran, televisi, internet, hingga jejaring sosial [11].

\section{B. Hoaks}

Berita yang dimanipulasi secara sengaja merupakan sebuah hoaks. Tujuan dari hoaks itu sendiri biasanya untuk memberikan berita yang salah dan bersifat menyesatkan [11]. Selain itu, hoaks juga bisa digunakan menjadi bahan untuk lelucon hingga menyebarkan ujaran kebencian ke satu pihak atau kelompok tertentu. Hal tersebut dapat mempengaruhi dan memberi dampak bagi penerimanya [12].

\section{Media Sosial}

Media sosial adalah media yang dapat dipakai oleh semua masyarakat dalam menunjukan ekspresi atau opini secara publik. Opini yang dipublikasi dapat berupa evaluasi (review), sentimen, maupun ungkapan emosi. Twitter adalah salah satu contoh media sosial yang banyak digunakan oleh masyarakat [13].

\section{Twitter}

Twitter ialah salah satu media sosial yang memungkinkan para penggunanya untuk membagikan informasi dengan batas maksimal 140 karakter [14].

\section{E. Algoritma Pembelajaran Mesin}

Algoritma yang digunakan dalam penelitian ini dijelaskan sebagai berikut:

1) Stochastic Gradient Descent (SGD): merupakan sebuah pendekatan sederhana dan efisien dalam melakukan klasifikasi secara linier menggunakan pembelajaran diskriminatif. Metode ini berupa algoritma optimasi iteratif (ulang) yang berguna untuk mencari titik fungsi minimum yang dapat diturunkan. Pada awal proses algoritma dimulai dengan melakukan penebakan. Kesalahan penebakan diperbaiki selama terjadi pengulangan tebakan menggunakan aturan gradien (turunan) dari fungsi yang akan diminimalkan. SGD memiliki kemampuan belajar lebih cepat dalam melakukan pelatihan klasifikasi. Selain itu, berdasarkan ukuran dataset latih tidak terbatas waktu pelaksanaannya [15].

2) Nä̈ve Bayes: Klasifikasi Nä̈ve Bayes mempunyai probabilitas sederhana dengan penerapan teori Bayes. Thomas Bayes adalah ilmuan Inggris yang menemukan metode ini yang digunakan untuk memprediksi peluang suatu peristiwa berdasarkan peristiwa yang pernah terjadi. Keuntungan pada klasifikasi ini yakni dibutuhkan hanyalah sejumlah data pelatihan yang kecil dalam mengestimasi skala yang dibutuhkan. Nä̈ve Bayes dalam kebanyakan kondisi bekerja sangat baik pada implementasi di dunia nyata yang kompleks dibandingkan dengan yang diharapkan [9].

3) Random Forest (RF): dilakukan dengan membangun banyak pohon klasifikasi data secara acak dan terdistribusi sama rata. Dari setiap pohon dipilih nilai yang paling sering muncul dalam kelasnya. Kesalahan generalisasi dalam penggolongan pohon tergantung pada keakuratan setiap pohon di RF serta korelasinya antar mereka [6].

Akurasi dapat ditingkatkan oleh RF karena terdapat pemilihan acak dalam menghidupkan anak simpul untuk setiap node (simpul di atasnya) serta hasil klasifikasi diakumulasikan dari setiap pohon. Setelah itu, hasil yang paling banyak muncul akan dipilih. Tingkat akurasi klasifikasi dipengaruhi oleh jumlah pohon yang dibentuk. Semakin banyaknya pohon, hasil yang didapat semakin akurat. RF juga dapat menangani input variabel yang besar serta menyeimbangkan unbalanced dataset yang mengalami error [9].

4) Rocchio: Teknik Rocchio berperan untuk mendapatkan batas antar kelas. Teknik yang digunakan adalah dengan menerapkan batasan dalam bentuk centroid. Centroid itu sendiri merupakan sebuah rata-rata dari semua vektor [16]

\section{METODE PENELITIAN}

Tahapan yang dilakukan dalam penelitian ini diilustrasikan secara sederhana pada Gambar. 1 diagram alir penelitian

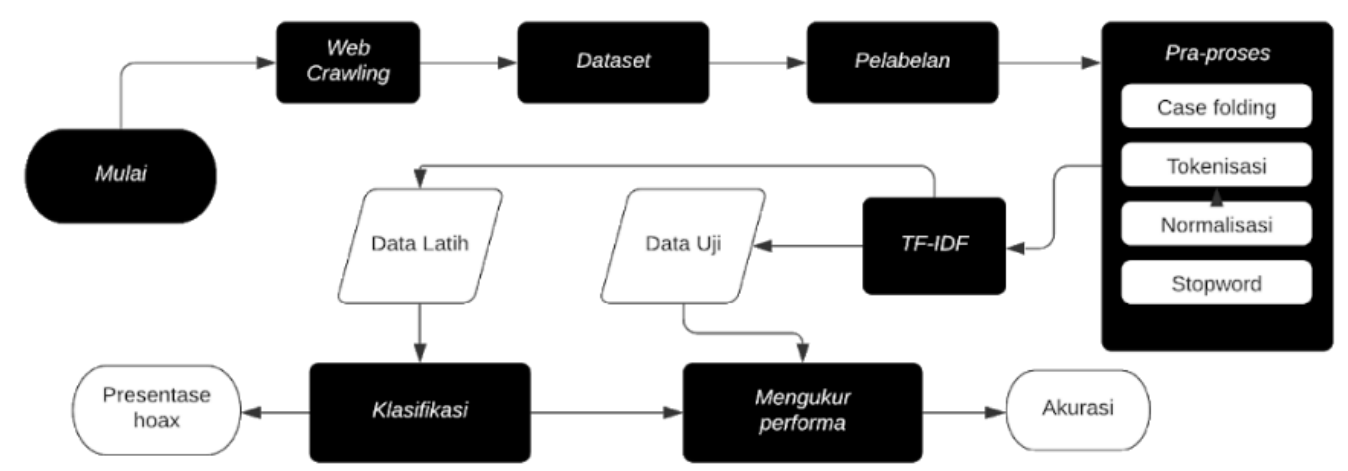

Gambar. 1 Diagram alir penelitian 


\section{A. Web Crawling}

Pengambilan data dilakukan dengan melakukan pemindaian (scanning) pada sebuah halaman web atau situs. Mencari atau merayapi data berupa informasi dari sebuah halaman adalah peran dari crawler web [17]. Tweet dari Twitter dipindai dengan bantuan akses Twitter developer dan dengan bahasa pemrograman Python. Gambar. 2 memperlihatkan hasil web crawling yang disimpan dalam bentuk Excel untuk nantinya diolah menjadi dataset.

\section{B. Dataset}

Tahap awal penelitian dilakukan dengan mengumpulkan data. Data tersebut didapat dari tweet yang mengandung informasi atau berita melalui Twitter dengan data yang didapatkan sebanyak 898 tweet. Topik tweet yang dikumpulkan mulai dari kesehatan, pemerintahan, hingga pendidikan. Dalam pencarian tweet yang mengandung topik tersebut digunakan kata kunci antara lain Corona, Mutasi Corona, PSBB, Dana Bansos, Dana Otsus, Utang Pemerintah, dan Sekolah Tatap Muka. Tweet yang telah didapat kemudian dicek kebenarannya secara manual. Pembagian bersifat subjektif dengan kriteria penilaian hoaks, berdasarkan tweet yang diambil dengan rentang waktu tertentu. Setelah itu data diberi label menjadi valid dan hoaks. Data tersebut dikumpulkan lalu dibagi menjadi data latih dan data uji.

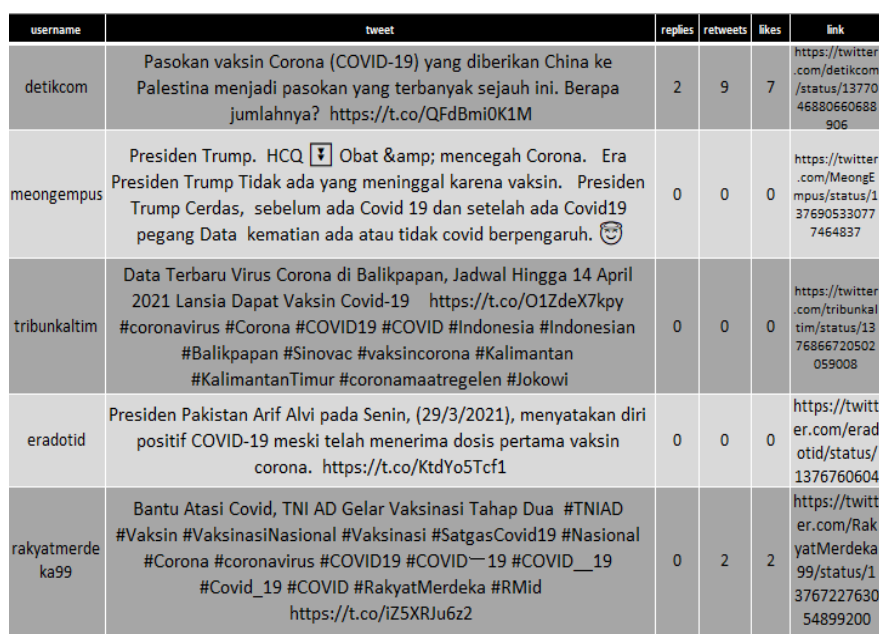

Gambar. 2 Hasil pemindaian tweet

\section{Pelabelan}

Pelabelan dilakukan secara manual untuk menentukan hoaks atau tidaknya suatu tweet. Pelabelan fakta dan hoaks tersebut dilakukan mengikuti Tabel I, yang berfungsi sebagai referensi proses pelabelan dataset yang telah dikumpulkan [10]. Pelabelan pada penelitian ini menggunakan atribut pada Twitter berupa username, link url, reply, dan hashtag yang menjadi bukti pendukung sebagai pemilihan hoaks atau validnya informasi pada tweet. Atribut provokasi dan sentimen menjadi penilaian terhadap tweet.
TABEL I

PENILAIAN TWEET BERISI HOAKS

\begin{tabular}{|l|l|}
\hline \multicolumn{1}{|c|}{ Atribut } & \multicolumn{1}{c|}{ Keterangan } \\
\hline Username & Melihat akun dari profil, asli, palsu, samaran. \\
\hline Tweet & $\begin{array}{l}\text { Kalimat yang tersusun dinilai dari informasi yang } \\
\text { terkandung, apakah fakta atau hoaks. }\end{array}$ \\
\hline Link Url & $\begin{array}{l}\text { Tweet } \text { mengandung } \text { link gambar atau } \text { url website, dapat } \\
\text { dinilai apakah berisi fakta atau hoaks. }\end{array}$ \\
\hline Reply & Jumlah balasan komentar. \\
\hline Hashtag & $\begin{array}{l}\text { Kerelevanan atau keterkaitan } \text { tweet dengan hashtag-nya } \\
\text { dapat dinilai apakah merupakan fakta atau hoaks. }\end{array}$ \\
\hline Provokasi & $\begin{array}{l}\text { Kalimat tweet yang mengandung kebencian, permusuhan } \\
\text { dan provokasi. }\end{array}$ \\
\hline Sentimen & $\begin{array}{l}\text { Kalimat } \text { tweet yang mengandung ke arah negatif ataupun } \\
\text { positif, sehingga tidak terkesan berat sebelah. }\end{array}$ \\
\hline
\end{tabular}

Pelabelan dilakukan secara manual dengan tabel penilaian seperti pada Tabel I [10]. Sesuai dengan atribut pada Tabel I, penulis menentukan tweet sebagai atribut utama. Lalu diurutkan atribut pendukung, dari Username untuk menilai akun tervertifikasi, asli, bodong atau samaran. Link Url berisi gambar atau website yang dapat dicek kebenarannya. Hastag, menilai hubungannya dengan isi tweet. Jika atribut diatas terpenuhi, sisa atribut pendukung tidak diperlukan. Namun jika tidak, makan atribut reply diperlukan untuk melihat balasan apakah mengandung informasi tambahan. dan dari 898 tweet berkurang menjadi 842 tweet. Pengelompokan dataset dibagi menjadi dua yaitu hoaks dan valid. Kriteria pada Tabel I digunakan sebagai acuan dalam penentuan hoaks dan validnya suatu data. Berdasarkan hasil pelabelan didapatkan sejumlah data hoaks dan valid seperti terlihat pada Tabel II.

TABEL II

JUMLAH DATA VALID DAN HOAKS

\begin{tabular}{|c|c|c|}
\hline Label & Jumlah & Persentase \\
\hline Valid & 483 & $57.36 \%$ \\
\hline Hoaks & 359 & $42.64 \%$ \\
\hline
\end{tabular}

\section{Pra-proses Data}

Tahap pra-proses berfungsi untuk mengubah hasil data mentah yang tidak terstruktur menjadi data yang terstruktur. Beberapa tahap yang dilalui dalam tahap ini antara lain case folding, tokenisasi, normalisasi, filtering, penghilangan stopwords, stemming, dan pembobotan kata (TF-IDF). Selanjutnya, data siap dibagi menjadi data latih dan data uji.

1) Case Folding: Data mentah yang telah dikumpulkan selanjutnya diproses melalui tahap case folding atau transform case [15]. Case folding yakni tahap dimana semua huruf pada teks diubah menjadi huruf kecil mulai dari karakter 'a' hingga ' $z$ ' [18]. Tabel III merupakan perbandingan sebelum dan setelah dilakukan tahap case folding. 
TABEL III

Perbandingan SEbelum dan SETElah TAHAP CASE FoldinG

\begin{tabular}{|c|c|c|}
\hline Tweet (sebelum) & Tweet (setelah) & Label \\
\hline Data Terbaru Virus Corona di & data terbaru virus corona di & \\
\hline Balikpapan, Jadwal Hingga 14 & balikpapan, jadwal hingga 14 & \\
\hline April 2021 Lansia Dapat & april 2021 lansia dapat vaksin & \\
\hline Covid-19 & covid-19 & \\
\hline https://t.co/O1ZdeX7kpy & https://t.co/o1zdex7kpy & \\
\hline \#coronavirus \#Corona & \#coronavirus \#corona & Valid \\
\hline \#COVID19 & \#covid19 \#covid & vallu \\
\hline \#Indonesian & \#indonesian \#balikpapan & \\
\hline \#Balikpapan & \#vaksincorona & \\
\hline \#vaksincorona \#Kalimantan & \#kalimantan & \\
\hline \#KalimantanTimur & \#kalimantantimur & \\
\hline \#coronamaatregelen \#Jokowi & \#coronamaatregelen \#jokowi & \\
\hline
\end{tabular}

2) Tokenisasi: Ekstraksi dari teks menjadi kata hingga dikumpulkan bagian terkecil dari dokumen adalah tokenisasi [18]. Kata-kata atau istilah disebut sebagai token. Saat proses tokenisasi, karakter yang nilainya seperti angka, tanda baca, dan karakter selain huruf alfabet akan dianggap sebagai pemisah kata (delimiter) dan tidak punya pengaruh akan teks atau kalimat utamanya. Tokenisasi juga dapat diartikan sebagai penguraian kalimat menjadi kata-kata serta menghilangkan tanda seperti titik (.), koma (,), hingga spasi dan juga karakter lain yang ada dalam sebuah kalimat [14].

Proses tokenisasi dalam penelitian ini menghilangkan (1) Mention ke pengguna lain (@), hashtag, angka; (2) Tautan url, simbol, emotikon, tweet duplikat; (3) Tanda baca titik (.), koma (,), tanya (?), dan sebagainya. Jika tweet mengandung tandatanda tersebut, maka akan melalui satu sampai tiga tahap proses tokenisasi. Hasil tokenisasi nantinya memuat tabel baru. Tabel IV merupakan perbandingan sebelum dan setelah dilakukan tahap tokenisasi.

TABEL IV

PERBANDINGAN SEBELUM DAN SETELAH TAHAP TOKENISAS

\begin{tabular}{|l|l|l|}
\hline Tweet (sebelum) & \multicolumn{1}{|c|}{ Tweet (setelah) } & Label \\
\hline $\begin{array}{l}\text { rusia klaim indonesia registrasi } \\
\text { obat covid-19 buatannya, 4 }\end{array}$ & $\begin{array}{l}\text { rusia klaim indonesia registrasi } \\
\text { obat covid buatanny hari }\end{array}$ & \\
hari sembuh **sekalipun & \\
avifavir sebagai obat anti- & sembuh sekalipun avifavir & \\
covid, obat ini tdk diberikan & sebagai obat anti covid obat ini & \\
kpd orang yg sehat. avifavir & diberikan kpd orang yg & Hoax \\
skn vaksin, melainkan obat utk & $\begin{array}{l}\text { sehavifavir bkn vaksin } \\
\text { melainkan obat utk }\end{array}$ & \\
menyembuhkan pasien yg & menyembuhkan pasien yg \\
terinfeksi virus corona & terinfeksi virus corona & \\
https://t.co/j8atwvfcyq & & \\
\hline
\end{tabular}

3) Normalisasi: digunakan sebagai pengoreksi kata singkat atau tidak jelas. Lata-kata tersebut dicocokkan dengan kamus. Selain itu, normalisasi berfungsi mengganti kata yang tidak baku menjadi baku [10]. Di media sosial khususnya Twitter, sebuah tweet seringkali mengandung kata gaul atau kata yang tidak baku. Tabel $\mathrm{V}$ merupakan perbandingan sebelum dan setelah dilakukan tahap normalisasi.
TABEL V

CONTOH PERUBAHAN KATA SEBELUM DAN SETELAH NORMALISASI

\begin{tabular}{|c|c|}
\hline Sebelum & Setelah \\
\hline gua & saya \\
sy & saya \\
yg & yang \\
km & kamu \\
gk & tidak \\
$\mathrm{g}$ & tidak \\
lu & kamu \\
ayooo & ayo \\
kmrn & kemarin \\
smpai & sampai \\
dmn & dimana \\
\hline
\end{tabular}

4) Penghilangan Stopword: kumpulan kata yang paling sering muncul dalam dokumen namun tidak mempresentasikan apapun. Oleh karena itu, diperlukan penghilangan stopword yang terdeteksi supaya tidak mempengaruhi pembobotan TDIDF [19]. Penghilangan stopword bertujuan untuk menyaring kata yang memiliki arti dan nilai yang lebih. Tabel VII merupakan perbandingan sebelum dan setelah dilakukan tahap penghilangan stopwords.

TABEL VI

PERbandingan SEbElum dan SETElaH PENGHILANGAN STOPWORDS

\begin{tabular}{|l|l|l|}
\hline Tweet (sebelum) & Tweet (setelah) & Label \\
\hline bangun dulu soal & & \\
jadi apa nantinya itu & & \\
belakangan di aceh & $\begin{array}{l}\text { bangun aceh dana } \\
\text { otsus melimpah } \\
\text { setelah dana otsus } \\
\text { melimpah banyak } \\
\text { sekali proyek } \\
\text { terbengkalai setelah } \\
\text { dibangun dibangun }\end{array}$ & Hoax \\
& & \\
\hline
\end{tabular}

5) Stemming: Hasil yang didapat dari penghilangan stopword disempurnakan kembali pada proses stemming [15]. Tahap stemming bertujuan untuk menemukan kata dasar dengan menghilangkan imbuhan (afiks) mulai dari awalan, sisipan, hingga akhiran, serta kombinasi dari awalan dan akhiran (sufiks) dari sebuah kata turunan. Proses ini dilakukan dengan mengubah bentuk sebuah kata menjadi kata dasar berdasarkan Bahasa Indonesia yang baik dan benar [19]. Stemming digunakan untuk mengamati pengaruh kata dasar dalam klasifikasi berita hoaks [8]. Tabel VII merupakan perbandingan sebelum dan setelah dilakukan tahap stemming. 
TABEL VII

PERBANDINGAN SEBELUM DAN SETELAH TAHAP STEMMING

\begin{tabular}{|c|c|c|}
\hline Tweet (sebelum) & Tweet (setelah) & Label \\
\hline kepala dinas & kepala dinas sehat & \\
kesehatan kabupaten & kabupaten & \\
jayapura khairul lie & jayapura khairul & \\
mengatakan program & lie program & \\
vaksinasi covid & vaksinasi covid & Valid \\
kabupaten jayapura & kabupaten & \\
papua telah & jayapura papua & \\
menggunakan dosis & dosis vaksin pon & \\
vaksin pon papua & papua dorong & \\
dorong umkm & umkm & \\
& & \\
\end{tabular}

\section{F. Seleksi Fitur dengan TF-IDF}

Langkah selanjutnya adalah seleksi fitur yang dilakukan dengan Term Frequency-Inverse Document Frequency (TFIDF) yakni menghitung bobot setiap kata pada tweet, baik dokumen uji maupun latih. Langkah ini bertujuan untuk memaparkan pentingnya peran kata dalam data menggunakan fitur gabungan unigram maupun bigram. Dengan begitu, didapatkan jarak antar dokumen yang merupakan hasil pembobotan dengan menggunakan vektor [18]. Gambar. 3 memperlihatkan hasil TF-IDF yang mentransformasi data berbentuk teks ke dalam bentuk vektor.

$(\theta, 1380)$
$(\theta, 338)$
$(\theta, 360)$
$(\theta, 358)$
$(\theta, 2082)$
$(\theta, 1408)$
$(1,1380)$
$(1,338)$
$(1,360)$
$(1,358)$
$(1,2082)$
$(1,1408)$
$(2,1440)$
$(2,1154)$
$(2,386)$
$(2,1426)$
$(2,335)$
$(2,1973)$
$(2,509)$
$(2,324)$
$(2,1332)$
$(2,654)$
$(2,2014)$
$(2,1528)$
$(2,360)$

$$
\begin{aligned}
& 0.38027973651551783 \\
& 0.3558467592023004 \\
& .1926619923667453 \\
& 0.14515023262962792 \\
& 0.19540151577383982 \\
& 0.7952304196011589 \\
& 0.38027973651551783 \\
& 0.35584675920230047 \\
& 0.19266199236674536 \\
& 0.14515023262962792 \\
& 0.7952304196011589 \\
& \text {. } 1866001027328286 \\
& 0.18660010273282862 \\
& .1653534023967889 \\
& 0.19344001249465262 \\
& 0.16858296657336688 \\
& 0.1624319062325245 \\
& 0.1441067020607491 \\
& 0.18101148953400975 \\
& 0.2146867128306923 \\
& .644060138492077 \\
& 0.29400886741027094
\end{aligned}
$$
0.43399865760829237 0.43399865760829237 0.43399865760829237 0.36948647851530053 0.2249682099120874 0.14127786386413677 0.14102243403428477 0.1400105202516809 0.3419965382232675 0.30815048474475937 0.32219786614093743 0.32219786614093743 0.32496898276436675 0.27430443126625126 0.25450575918392115 0.1046941655862382 0.26855314058009916 0.20788585435252346 0.17928654644113654 0.22956238227195117 0.20661232430923496 0.2808247068766609

Gambar. 3 Hasil vektor pembobotan dengan TF-IDF

\section{G. Klasifikasi}

Klasifikasi merupakan sebuah analisis data dengan mengekstrak suatu model untuk mempresentasikan kelas data. Model yang disusun mencakup pengklasifikasian serta prediksi kategori kelas label. Teknik klasifikasi dapat diimplementasikan dalam banyak bidang, salah satunya adalah deteksi penipuan [11].

Setelah tahap TF-IDF maka akan dilakukan klasifikasi dengan algoritma yang digunakan, yaitu SGD, Naïve Bayes, Random Forest dan Rocchio. Keempat algoritma tersebut akan dibandingkan performanya dan dievaluasi kinerjanya dengan mengukur presisi, recall, nilai F-1, dan akurasinya.

\section{HASIL DAN PEMBAHASAN}

Setelah dataset dipra-proses hingga diseleksi fiturnya dengan TF-IDF, selanjutnya dibagi menjadi data uji dan data latih. Total dari 842 tweet yang telah diberi label, selanjutnya dipra-proses dan menyisakan 810 tweet menjadi suatu informasi singkat dengan kalimat yang baku. Perbandingan yang digunakan untuk setiap klasifikasi dibagi menjadi data latih dan uji dengan perbadingan 60:40, 70:30, 80:20, 90:10. Tabel VIII merupakan tabel pembagiannya.

Semua proses perhitungan dalam penelitian ini menggunakan bahasa pemrograman Python, dengan antarmuka Jupyter Notebook dan Visual Studio Code. Rumus perhitungan atau library dapat diakses secara open source dan dapat digunakan sesuai kepentingan para developer.

TABEL VIII

PEMBAGIAN JUMLAH TWEET UNTUK DATA LATIH DAN UJI

\begin{tabular}{|l|c|c|c|c|}
\hline \multirow{2}{*}{ Dataset Tweet } & \multicolumn{4}{|c|}{ Pembagian Jumlah Tweet (810) } \\
\cline { 2 - 5 } & $\mathbf{6 0 : 4 0}$ & $\mathbf{7 0 : 3 0}$ & $\mathbf{8 0 : 2 0}$ & $\mathbf{9 0 : 1 0}$ \\
\hline Latih & 468 & 567 & 648 & 729 \\
\hline Uji & 324 & 243 & 162 & 81 \\
\hline
\end{tabular}

Hasil pembagian digunakan untuk mengetahui performa tiap algoritma klasifikasi dan selanjutnya dievaluasi melalui perhitungan nilai presisi, recall, F-1, dan akurasi. Tabel IX merupakan pembagian data latih dan data uji.

TABEL IX

CONFUSION MATRIX

\begin{tabular}{|c|c|c|}
\hline \multirow{2}{*}{ Faktual } & \multicolumn{2}{|c|}{ Prediksi } \\
\cline { 2 - 3 } & Valid & Hoaks \\
\hline Valid & True positive $(T P)$ & False negative $(F N)$ \\
\hline Hoaks & False positive $(F P)$ & True negative $(T N)$ \\
\hline
\end{tabular}

Saat melakukan perhitungan, prediksi pada True Positive (TP) akan menunjukkan hasil faktual yang valid sama seperti yang dimuat di dataset. False Positive (FP) terjadi ketika prediksi ternyata tidak hoaks tapi dimuat sebagai tweet hoaks. True Negative (TN) dinyatakan saat prediksi benar sebagai hoaks. False Negative (FN) adalah saat tweet hoaks tapi dimuat sebagai valid. Tabel IX adalah tabel kombinasi yang nantinya digunakan untuk memprediksi nilai dari akurasi, presisi, recall, dan F-1

\section{A. Akurasi}

Akurasi diartikan sebagai tingkat kedekatan nilai dari hasil prediksi yang benar dari nilai aktual [20]. Dari Tabel IX, confusion matrix dapat digunakan untuk menghitung persen akurasi dari model klasifikasi dengan Rumus (1).

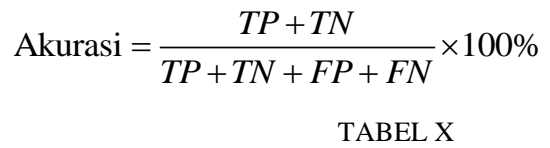

HASIL AKURASI DARI TIAP ALGORITMA KLASIFIKASI

\begin{tabular}{|l|c|c|c|c|}
\hline \multirow{2}{*}{ Algoritma } & \multicolumn{4}{|c|}{ Akurasi (\%) } \\
\cline { 2 - 5 } & $\mathbf{6 0 : 4 0}$ & $\mathbf{7 0 : 3 0}$ & $\mathbf{8 0 : 2 0}$ & $\mathbf{9 0 : 1 0}$ \\
\hline SGD & 83.95 & 84.77 & 84.56 & 86.41 \\
\hline Nä̈ve Bayes & 81.48 & 83.12 & 82.09 & 81.48 \\
\hline Random Forest & 80.55 & 80.24 & 81.48 & 82.71 \\
\hline Rocchio & 74.07 & 73.25 & 78.39 & 72.83 \\
\hline
\end{tabular}


Berdasarkan Tabel X dapat dilihat bahwa algoritma terbaik pada perhitungan akurasi adalah SGD dengan data latih dan uji 90:10 sebesar $86.41 \%$. SGD juga tetap memiliki akurasi terbaik dibandingkan algoritma lain dengan posisi tertinggi kedua $84.77 \%$ pada perbandingan $70: 30$, dan ketiga $84.56 \%$ pada perbandingan 80:20. Pada hasil algoritma Nä̈ve bayes dan Random Forest nilai akurasi-nya tidak berbeda jauh. Hasil ratarata masing-masing algoritma mulai dari SGD, Nä̈ve Bayes, Random Forest, Rocchio secara berurutan adalah $84.87 \%$, $82.02 \%, 81.25 \%, 74.64 \%$.

\section{B. Presisi}

Presisi adalah perbandingan untuk mengukur keakuratan seluruh hasil dataset dan mengetahui hasil klasifikasi kategori yang sebenarnya. Presisi dapat juga diartikan sebagai kecocokan antara sebuah pertanyaan dengan jawaban atau informasi yang diberikan [21]. Presisi merupakan hasil dari perhitungan yang benar (TP) dibagi dengan jumlah data yang terindentifikasi oleh sistem. Rumus presisi diberikan pada Rumus (2).

$$
\text { Presisi }=\frac{T P}{T P+F P} \times 100 \%
$$

TABEL XI

HASIL PRESISI DARI TIAP ALGORITMA KLASIFIKASI

\begin{tabular}{|l|c|c|c|c|}
\hline \multirow{2}{*}{ Algoritma } & \multicolumn{4}{|c|}{ Presisi (\%) } \\
\cline { 2 - 5 } & $\mathbf{6 0 : 4 0}$ & $\mathbf{7 0 : 3 0}$ & $\mathbf{8 0 : 2 0}$ & $\mathbf{9 0 : 1 0}$ \\
\hline SGD & 78.41 & 75.67 & 76.71 & 91.17 \\
\hline Nä̈ve Bayes & 83.33 & 85.33 & 85.71 & 77.41 \\
\hline Random Forest & 78.57 & 72.64 & 86.95 & 75.00 \\
\hline Rocchio & 69.23 & 74.01 & 76.74 & 71.42 \\
\hline
\end{tabular}

Sama halnya dengan akurasi, pada perhitungan presisi, seperti pada Tabel XI, algoritma SGD dengan perbandingan 90:10 masih memiliki hasil terbaik. Namun, jika dilihat dari perbandingan data latih dan data uji, presisi pada SGD tergolong tidak stabil. Algoritma Naive Bayes menghasilkan nilai presisi yang lebih stabil dibandingkan SGD, dengan presisi tertinggi sebesar $85.71 \%$ pada perbandignan 80:20. Selain itu Random Forest juga memiliki hasil yang cukup baik, yaitu sebesar $86.95 \%$, namun juga tidak stabil seperti SGD. Hasil rata-rata masing-masing algoritma mulai dari SGD, Naive Bayes, Random Forest, Rocchio secara berurutan adalah $80.49 \%, 82.95 \%, 78.29 \%, 72.85 \%$.

\section{Recall}

Tingkat kesuksesan sebuah sistem dalam mendeteksi suatu kelompok menjadi sebuah parameter recall. Recall merupakan perhitungan dari pembagian antara jumlah data yang benar dengan jumlah yang seharusnya [20]. Rumus recall diberikan pada Rumus (3).

$$
\text { Recall }=\frac{T P}{T P+F N} \times 100 \%
$$

TABEL XII

HASIL RECALL DARI TIAP ALGORITMA KLASIFIKASI

\begin{tabular}{|l|c|c|c|c|}
\hline \multirow{2}{*}{ Algoritma } & \multicolumn{4}{|c|}{ Recall (\%) } \\
\cline { 2 - 5 } & $\mathbf{6 0 : 4 0}$ & $\mathbf{7 0 : 3 0}$ & $\mathbf{8 0 : 2 0}$ & $\mathbf{9 0 : 1 0}$ \\
\hline SGD & 83.84 & 89.36 & 87.50 & 79.48 \\
\hline Nä̈ve Bayes & 65.38 & 68.08 & 65.62 & 75.00 \\
\hline Random Forest & 77.46 & 81.91 & 74.07 & 84.37 \\
\hline Rocchio & 79.59 & 78.33 & 81.48 & 81.39 \\
\hline
\end{tabular}

Berdasarkan Tabel XII, SGD menjadi algoritma terbaik dengan pencapaian tertinggi $89.36 \%$ pada data latih dan uji 70:30. Posisi kedua juga tidak jauh berbeda sebesar $87.50 \%$ pada perbandingan $80: 20$, lalu diikuti $83.84 \%$ pada perbandingan 60:40. Uniknya, Rocchio memiliki nilai terbaiknya pada perhitungan recall sebesar $81.48 \%$ dan stabil. Hasil rata-rata masing-masing algoritma mulai dari SGD, Naive Bayes, Random Forest, Rocchio secara berurutan adalah $85.05 \%, 68.52 \%, 79.45 \%, 80.20 \%$.

\section{D. $F-1$}

Nilai F-1 atau yang disebut juga dengan harmonic mean, digambarkan sebagai pengaruh relatih dari sebuah presisi dan recall. F-1 sendiri dapat menunjukkan performa akan suatu metode yang dipakai [21]. Rumus F-1 diberikan pada Rumus (4).

$$
\begin{gathered}
\mathrm{F}-1=\frac{2 \times \text { recall } \times \text { presisi }}{\text { recall }+ \text { presisi }} \times 100 \% \\
\text { TABEL XIII } \\
\text { HASIL F-1 DARI TIAP ALGORITMA KLASIFIKASI }
\end{gathered}
$$

\begin{tabular}{|l|c|c|c|c|}
\hline \multirow{2}{*}{ Algoritma } & \multicolumn{4}{|c|}{ Akurasi (\%) } \\
\cline { 2 - 5 } & $\mathbf{6 0 : 4 0}$ & $\mathbf{7 0 : 3 0}$ & $\mathbf{8 0 : 2 0}$ & $\mathbf{9 0 : 1 0}$ \\
\hline SGD & 81.04 & 81.95 & 81.75 & 84.93 \\
\hline Nä̈ve Bayes & 73.27 & 75.73 & 74.33 & 76.19 \\
\hline Random Forest & 78.01 & 77.00 & 79.99 & 79.41 \\
\hline Rocchio & 78.39 & 76.11 & 79.04 & 76.08 \\
\hline
\end{tabular}

Pada perhitungan F-1 pada Tabel XIII, SGD dominan menjadi algoritma klasifikasi terbaik dengan perolehan nilai $84.93 \%, 81.95 \%, 81.75$, dan $81.04 \%$ pada perbandingan $90: 10$, 70:30, 80:20, dan 60:40. Jika melihat algoritma lain, sebenarnya Random Forest juga tidak kalah jauh karena memiliki nilai hampir $80 \%$. Hasil rata-rata masing-masing algoritma SGD, Naive Bayes, Random Forest, Rocchio secara berurutan adalah $82.41 \%, 74.88 \%, 78.60 \%, 76.32 \%$.

Berdasarkan Gambar. 4 dan Gambar. 5 dapat dilihat bahwa persentase keempat algoritma dari akurasi, presisi, recall, hingga F-1 mengalami fluktuasi. SGD memiliki rata-rata yang cukup stabil namun mengalami fluktuasi dengan selisih yang cukup besar. Hal tersebut menunjukkan bahwa hasil penelitian ini sesuai dengan grafik iterasi pengujian model SGD dalam 10 kali percobaan (Cross-Validation 10) dalam [15], dimana SGD mengalami fluktuasi namun cukup stabil dengan selisih yang cukup besar dan terkadang mendapat nilai tertingginya. 


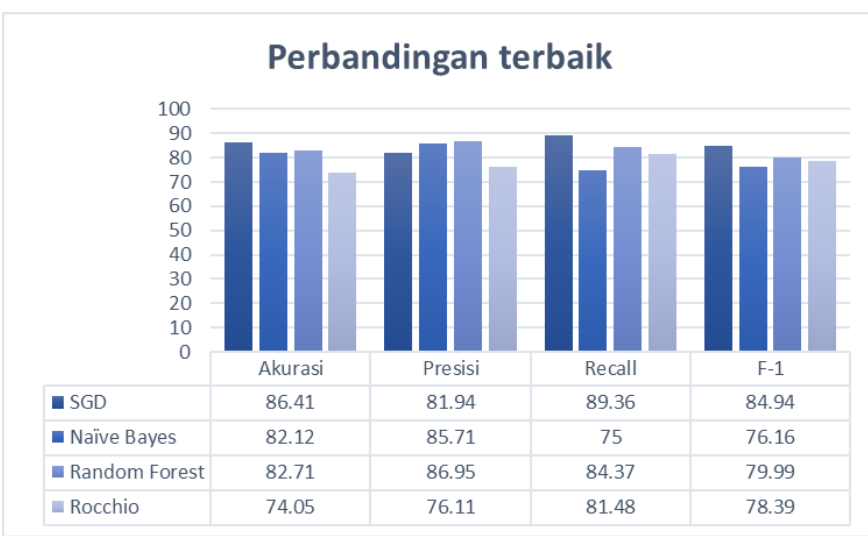

Gambar. 4. Perbandingan terbaik dari akurasi, presisi, recall, dan F-1

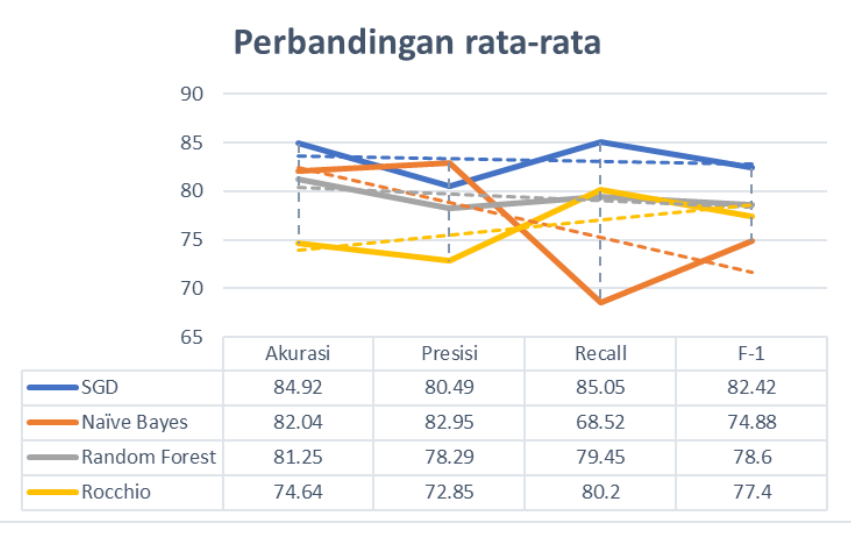

Gambar. 5 Perbandingan rata-rata dari akurasi, presisi, recall, dan F-1

Nä̈ve Bayes memiliki fluktuasi paling besar dengan perubahan persentase yang cukup drastis. Secara keseluruhan persentase terendah ditemukan pada algoritma Rocchio, namun cenderung naik diikuti oleh Random Forest yang cukup stabil dengan fluktuasi selisih yang kecil. Pada penelitian [7], nilai akurasi Rocchio menunjukkan hasil klasifikasi yang lebih baik jika dibandingkan dengan Naive Bayes. Hal tersebut dikarenakan total kesalahan klasifikasi data uji pada Rocchio lebih rendah dibanding Naive Bayes. Pada Naive Bayes dapat terjadi kasus underflow atau rendahnya perolehan nilai peluang mengakibatkan klasifikasi ini sulit untuk membaca data. Hal tersebut menjadi alasan Naive Bayes memiliki nilai akurasi yang rendah.

Random Forest adalah algoritma yang dapat mengembangkan hasil klasifikasinya dengan menerapkan fitur acak untuk setiap data yang dipanggil, sehingga dapat meningkatkan akurasinya [9]. Metode yang digunakan dengan membangun pohon keputusan ini memiliki hasil fluktuasi penurunan terbesar dalam perbandingan rata-rata. Hal tersebut dikarenakan Random Forest adalah salah satu algoritma klasifikasi yang dapat membuat banyak data sekaligus dengan sistem acak, yang dapat meningkatkan akurasi juga mengalami penurunan.

\section{KeSIMPULAN}

Dari hasil dan pembahasan didapatkan kesimpulan bahwa identifikasi tweet dari Twitter yang mengandung berita atau informasi hoaks dapat diklasifikasi dengan pembelajaran mesin. Pada penelitian ini digunakan berita tentang kesehatan dengan kata kunci perpanjang PSBB, mutasi corona, vaksin, covid-19; pendidikan dengan kata kunci sekolah dan sekolah tatap muka; pemerintahan dengan kata kunci dana otsus, dana bansos, utang pemerintah. Total setelah pra-proses berjumlah 810 tweet dibagi menjadi dua label antara lain valid dan hoaks. Pada label valid ditemukan sebanyak 483 tweet, sedangkan pada label hoaks sebanyak 359 tweet.

Berita hoaks dan valid dapat diklasiikasi dengan pembelajaran mesin menggunakan empat algoritma klasifikasi yang berbeda, yaitu SGD, Naive Bayes, Random Forest, Rocchio serta menggunakan tahapan pra-proses (case folding, tokenisasi, normalisasi, penghilangan stopwords, stemming), dan seleksi fitur TF-IDF.

Dari hasil perbandingan dapat disimpulkan bahwa algoritma SGD memiliki akurasi, recall, dan F-1 terbaik yaitu masing-masing sebesar $86.41 \%, 89.36 \%$, dan $84.39 \%$, sedangkan hasil terbaik pada presisi diperoleh dari algoritma Random Forest, yaitu sebesar $86.95 \%$. Sementara itu, untuk perbandingan rata-rata akurasi, recall, dan F-1 terbaik ditemukan pada algoritma SGD dengan hasil secara berturut sebesar $84.92 \%, 85.05 \%$, dan $82.42 \%$. sedangkan pada perbandingan rata-rata presisi tertinggi diperoleh algoritma Naive Bayes sebesar $82.95 \%$.

Dengan hasil presentase yang disajikan, maka SGD menjadi algoritma terbaik dalam mengidentifikasi tweet hoaks di Twitter, karena memiliki kemampuan yang baik pada data berdimensi tinggi dan ingatan yang tinggi juga dapat memperbaiki hasil dari ingatan sebelumnya. Random Forest merupakan algoritma terbaik kedua yang dapat meningkatkan akurasi dengan memanggil simpul pohon yang lainnya dan lebih baik dalam menangani data yang besar. Hasil Random Forest dinilai cukup baik, karena menghasilkan fluktuasi yang stabil pada penelitian ini. Namun akan lebih baik jika data yang dimiliki lebih banyak.

Naive Bayes dengan teorema Bayes-nya yang menerapkan klasifikasi sederhana dan semua fitur dianggap tidak saling berhubungan, ternyata tidak cukup baik menangani klasifikasi pada penelitian ini sehingga terjadi fluktuasi presentase penurunan yang cukup besar dari hasil presisi $82.95 \%$ menjadi $68.52 \%$ pada recall dan $74.88 \%$ pada F-1. Pada posisi terakhir algoritma Rocchio walaupun memiliki kinerja yang lebih baik daripada Nä̈ve Bayes pada penelitian lain, dengan melakukan perhitungan batas kelas menggunakan centroid untuk mendapatkan hasil batas-batasnya ternyata memiliki selisih yang cukup jauh dengan Nä̈ve Bayes pada penelitian ini. Walaupun memiliki performa terburuk, tetapi Rocchio mengalami fluktasi kenaikan yang cukup baik pada recall dan F-1. Hal ini dikarenakan Rocchio hanya melakukan pendekatan dalam mencari kemiripan dengan centroid kelas sehingga melupakan data lain yang berbeda pada penelitian ini.

Kesimpulan akhir didapatkan bahwa perubahan persentase yang paling stabil ditemukan pada algoritma Random Forest dengan selisih perubahan kecil dan SGD yang memiliki selisih cukup besar. Fluktuasi terbesar ditemukan pada algoritma Naïve Bayes dengan penurunan dan Rocchio dengan kenaikan yang cukup drastis. 


\section{REFERENSI}

[1] J. Hutahaean, Konsep Sistem Informasi, 1st ed. Yogyakarta: Deepublish, 2014.

[2] Asosiasi Penyelenggara Jasa Internet Indonesia (APJII), "Laporan Survei Internet APJII 2019 - 2020 [Q2]," 2020 https://www.apjii.or.id/survei.

[3] Masyarakat Telematika Indonesia (Mastel), "Hasil Survey Wabah Hoax Nasional 2019," 2019. https://mastel.id/hasil-survey-wabahhoax-nasional-2019/.

[4] A. B. Prasetijo, R. R. Isnanto, D. Eridani, Y. A. A. Soetrisno, M. Arfan and A. Sofwan, "Hoax detection system on Indonesian news sites based on text classification using SVM and SGD," Proc. - 2017 4th Int. Conf. Inf. Technol. Comput. Electr. Eng. ICITACEE 2017, vol. 2018-Janua, pp. 45-49, 2017, doi: 10.1109/ICITACEE.2017.8257673.

[5] J. C. W. Pantouw, "Perbandingan klasifikasi rocchio dan multinomial naïve bayes pada analisis sentimen data twitter bahasa indonesia," Dep. Ilmu Komput. Fak. Mat. Dan Ilmu Pengetah. Alam Inst. Pertan. Bogor 2017, 2017.

[6] M. D. Nugraha, J. A. Utama, and S. Sulistiani, "Implementasi Metode Random Forest Dalam Memprediksi Peristiwa Flare," Pros. Semin. Nas. Fis., pp. 258-263, 2018.

[7] A. Afriza and J. Adisantoso, "Metode Klasifikasi Rocchio untuk Analisis Hoax Rocchio Classification Method for Hoax Analysis," J. Ilmu Komput. Agri-Informatika, vol. 5, pp. 1-10, 2018, [Online] Available: http://journal.ipb.ac.id/index.php/jika.

[8] E. Rasywir and A. Purwarianti, "Eksperimen pada Sistem Klasifikas Berita Hoax Berbahasa Indonesia Berbasis Pembelajaran Mesin,” J Cybermatika, vol. 3, no. 2, pp. 1-8, 2015, [Online]. Available: https://www.mendeley.com/import/.

[9] T. Trisna Astono Putri, H. S. Warra, I. Yanti Sitepu, and M Sihombing, "Analysis and Detection of Hoax Contents in Indonesian News Based on Machine Learning," J. Informatics Pelita Nusant., vol 4, no. 1, pp. 19-26, 2019, [Online]. Available: http://ejurnal.pelitanusantara.ac.id/index.php/JIPN/article/view/489/291.

[10] B. Irena and Erwin Budi Setiawan, "Fake News (Hoax) Identification on Social Media Twitter using Decision Tree C4.5 Method," J. RESTI (Rekayasa Sist. dan Teknol. Informasi), vol. 4, no. 4, pp. 711-716, 2020, doi: 10.29207/resti.v4i4.2125

[11] H. Mustofa and A. A. Mahfudh, "Klasifikasi Berita Hoax Dengan Menggunakan Metode Naive Bayes," Walisongo J. Inf. Technol., vol 1, no. 1, p. 1, 2019, doi: 10.21580/wjit.2019.1.1.3915.

[12] C. Juditha, "Hoax Communication Interactivity in Social Media and Anticipation (Interaksi Komunikasi Hoax di Media Sosial serta Antisipasinya)," J. Pekommas, vol. 3, no. 1, p. 31, 2018, doi: 10.30818/jpkm.2018.2030104.

[13] B. Liu, Sentiment Analysis and Opinion Mining, no. April. 2012

[14] B. Kurniawan, M. A. Fauzi, and A. W. Widodo, "Klasifikasi Berita Twitter Menggunakan Metode Improved Naïve Bayes," J. Pengemb. Teknol. Inf. dan Ilmu Komput. Univ. Brawijaya, vol. 1, no. 10, pp. 1193-1200, 2017

[15] R. Umar, I. Riadi, and P. Purwono, "Klasifikasi Kinerja Programmer pada Aktivitas Media Sosial dengan Metode Stochastic Gradient Descent," JOINTECS (Journal Inf. Technol. Comput. Sci., vol. 5, no. 2, p. 55, 2020, doi: 10.31328/jointecs.v5i2.1324.

[16] F. R. Lumbanraja, J. I. Komputer, and F. U. Lampung, "Sistem Pencarian Data Teks dengan Menggunakan Metode Klasifikasi Rocchio ( Studi Kasus : Dokumen Teks Skripsi ),” 2013.

[17] R. R. Muzad Aad Miqdad, "Korpus Berita Daring Bahasa Indonesia Dengan Depth First Focused Crawling," Sentrinov (Seminar Nas. Terap. Ris. Inov., vol. 2, no. 1, pp. 11-20, 2016.

[18] F. N. Rozi and D. H. Sulistyawati, "Klasifikasi Berita Hoax Pilpres Menggunakan Metode Modified K-Nearest Neighbor Dan Pembobotan Menggunakan Tf-Idf," Konvergensi, vol. 15, no. 1, 2019, doi: 10.30996/konv.v15i1.2828.

[19] D. Maulina and R. Sagara, "Klasifikasi Artikel Hoax Menggunakan Support Vector Machine Linear Dengan Pembobotan Term Frequency-Inverse Document Frequency," J. Mantik Penusa, vol. 2, no. 1 , pp. $35-40,2018$.

[20] C. A. Ul Hassan, M. S. Khan, and M. A. Shah, "Comparison of machine learning algorithms in data classification," ICAC $2018-2018$ 24th IEEE Int. Conf. Autom. Comput. Improv. Product. through Autom. Comput., no. September, pp. 1-6, 2018, doi:
10.23919/IConAC.2018.8748995.

[21] A. A. Puspitasari, E. Santoso, and Indriati, "Klasifikasi Dokumen Tumbuhan Obat Menggunakan Metode Improved k-Nearest Neighbor," J. Pengemb. Teknol. Inf. dan Ilmu Komput., vol. 2, no. 2, pp. 486-492, 2018. 